\title{
Comparative Study of Transudate and Exudate Pleural Fluid Using C-reactive Protein, Uric Acid and Malondialdehyde as Markers
}

\author{
Anurag Yadav ${ }^{1}$, Ramlingareddy ${ }^{2}$ Malathi $\mathrm{M}^{3}$
}

\begin{abstract}
Introduction: Pleural effusion is one of the most important debilitating disorders caused by various pathological conditions. It is a common clinical disorder and is either a manifestation or a complication of one or other respiratory of non-respiratory diseases. Diagnosing the type of effusion as an exudate or transudate is equally important in identifying the cause and treating accordingly to the type of pleural effusion. Hence, the use of light's criteria to separate transudate from exudate has been generally the admitted first step in any study of pleural effusion of the unknown cause. As the pleural effusion may increase the local oxidative stress so that pleural fluid can be analyzed for the oxidative stress marker as one of the tool additives with the light's criteria for the better differentiating the exudative from transudative type of effusion. Aim: Estimate levels of malondialdehyde (MDA), C-reactive protein (CRP) and uric acid in pleural fluid and compare the levels in exudative and transudative pleural fluid.

Materials and methods: The samples for the study were collected after taking informed consent. The pleural tapping was done under all required aseptic precaution. It was divided into two groups-transudative pleural effusion (group 1) and exudative pleural effusion (group 2) by using Light's criteria. Samples were analyzed for the MDA, CRP and uric acid.

Results and conclusion: MDA and CRP values have shown significantly increased levels in the pleural fluid of exudative type compared to transudative, but pleural uric acid levels were lower in exudative. However, there was no much difference between these parameters in serum levels among groups. The present study showed that oxidative stress is more in the exudates compared to transudates, probably due to the higher production of reactive oxygen species; it may serve as markers for differentiating between exudates and transudates.
\end{abstract}

Keywords: C-reactive protein, Malondialdehyde, Uric acid.

Indian Journal of Medical Biochemistry (2019): 10.5005/jp-journals-10054-0084

\section{INTRODUCTION}

$\mathrm{P}$ eural effusion is one of the most important debilitating disorders caused by various pathological conditions. It is a common clinical disorder and is either a manifestation or a complication of one or other respiratory of non-respiratory diseases. ${ }^{1}$ It has prognosis if not diagnosed or treated properly. Approximately, one million patients develop pleural effusion each year. Most of the cases, cause of the effusion is obvious, and sometimes it's a challenge for diagnosing the cause. ${ }^{2}$ Diagnosing the type of effusion as an exudate or transudate is equally important in identifying the cause and treating accordingly to the type of pleural effusion. Hence, use of Light's criteria to separate transudate from exudate has been generally the admitted first step in any study of pleural effusion of the unknown cause. The most widely accepted is light's criteria i.e., (a) pleural protein to serum protein ratio greater than 0.5 (b) pleural LDH is $>200 \mathrm{IU} / \mathrm{L}$, denoting exudative type and (c) pleural fluid to serum $\mathrm{LDH}$ ratio greater than $0.6 .^{3}$ As the pleural effusion may increase the local oxidative stress, hence the pleural fluid can be analyzed for the oxidative stress marker as one of the tool additives with the light's criteria for the better differentiating the exudative from transudative type of effusion. One such marker is malondialdehyde (MDA) which is a lipid peroxidation product formed under the oxidative free radical damage. C-reactive protein (CRP) and uric acid in the pleural fluid can even be used as the additive for diagnosing the type of effusion.

\section{Review of literature}

A study conducted by Jain using the uric acid as a new marker for the differentiation between exudates and transudates in pleural effusion cases divided using the Light's criteria, showed a significant

\author{
${ }^{1,2}$ Assistant Professor, ${ }^{3}$ Professor and Head \\ ${ }^{1-3}$ Department of Biochemistry, Father Muller Medical College, \\ Mangaluru, Karnataka, India
}

Corresponding Author: Ramlingareddy, Assistant Professor, Department of Biochemistry, Father Muller Medical College, Mangaluru, Karnataka, India, Phone: +919964204665, e-mail: ramlingreddy2020@ yahoo.co.in

How to cite this article: Yadav A, Ramlingareddy, Malathi $M$. Comparative Study of Transudate and Exudate Pleural Fluid Using C-reactive Protein, Uric Acid and Malondialdehyde as Markers. Indian J Med Biochem 2019;23(1):193-196.

Source of support: Nil

Conflict of interest: None

difference and the utility to aid the current criteria and they found the increased levels of uric acid in the transudate effusion compared to the exudate fluid. The ratio of pleural to serum level was $>1$ in the transudate against exudate $<1 .{ }^{4}$

Study conducted by Usha Kiran, evaluating the levels of oxidative stress and local inflammatory status by using malondialdehyde (MDA) in the pleural fluid and blood of patients with the pleural effusion of various etiologies, showed the increase levels of stress markers in exudate compared to transudates, probably due to the production of the reactive oxygen species and may be used as a marker for differentiating between the transudates and exudates. ${ }^{5}$

A study conducted by Gupta, evaluation of pleural fluid and serum MDA in differentiating the transudate from exudative pleural fluid. The study has shown a significant difference between the transudate and exudate, and the cutoff point was also

(c) The Author(s). 2019 Open Access This article is distributed under the terms of the Creative Commons Attribution 4.0 International License (https://creativecommons. org/licenses/by-nc/4.0/), which permits unrestricted use, distribution, and non-commercial reproduction in any medium, provided you give appropriate credit to the original author(s) and the source, provide a link to the Creative Commons license, and indicate if changes were made. The Creative Commons Public Domain Dedication waiver (http://creativecommons.org/publicdomain/zero/1.0/) applies to the data made available in this article, unless otherwise stated. 
demonstrated using the receiver operating curve ( $R O C)$ and even concluded with the usage of the MDA as a marker and better utility than the traditional light's criteria. ${ }^{6}$

\section{Aims and objectives}

- Estimation of MDA, C-reactive protein (CRP) and uric acid in pleural fluid.

- Compare the levels of MDA, CRP and uric acid in exudative and transudative pleural fluid.

\section{Materials and Methods}

It is an observational analytical study, which was be conducted at Father Muller Medical College Hospital Clinical Biochemistry Laboratory for the period of 3 months. The study was conducted with self expenditure. A total number of 75 patients of pleural effusion were included in the study (sample size was achieved by using the sample size calculator for the power of $>80 \%$ and alpha value $<0.05)$ (Graph 1).

The pleural taping was done with the consent of the patient after providing the required information and under all required aseptic precaution. The sample of pleural fluid sent for the analysis of biochemical parameters for the biochemistry laboratory is stored in a deep freezer $\left(-20^{\circ} \mathrm{C}\right)$ by making aliquots for the purpose of the study.

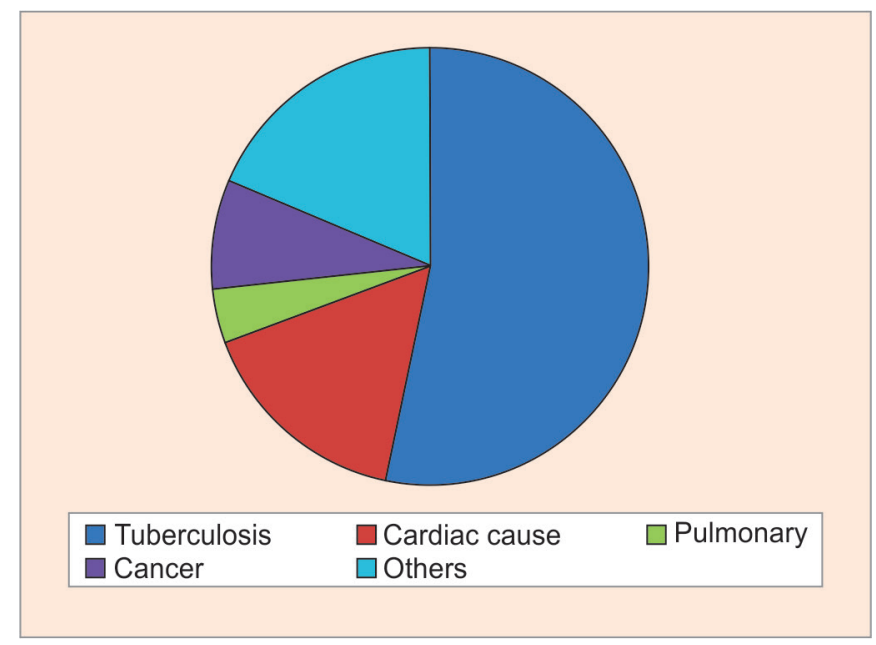

Graph 1: Frequency distribution for the cause of the pleural effusion
Inclusion of all the pleural effusion cases caused because of respiratory or non-respiratory diseases. The pleural effusion because of any traumatic causes was excluded from the study.

The study groups are made as group 1-transudative pleural effusion, group 2-exudative pleural effusion. The groups are allotted according to the Light's criteria to diagnose the type of effusion fluid. The following analysis was done in pleural samples for the study; MDA by using the TBARS method, CRP and uric acid using Kit, in pleural fluid and serum samples. Other required data of the included subjects are accessed from the hospital information system.

\section{Statistics}

Collected data were analyzed using the SPSS version 23 package tool. The descriptive data are presented as mean $\pm S D$, the mean difference between variables are compared using students t-test, and strength of association among the variables is estimated by the Pearson correlation coefficient. The $p$ value less than 0.05 was considered statistically significant and the strength of the study was taken to be more than $80 \%$.

\section{Results}

Total of 75 individuals is included in the current study, divided into two groups: as transudative pleural effusion and exudative pleural effusion with 21 (28\%) and 54 (72\%) subjects in each group respectively. The etiological cause for the pleural effusion and the gender distribution presented (Tables 1 to 3 ).

\section{Discussion}

In abnormal states, the pleural fluid will get accumulated in the pleural space because of respiratory and non-respiratory causes. Generally, it is due to decreased fluid absorption and increased fluid formation. Determining the cause of the pleural effusion is not always an easy task, hence first and most critical step in evaluation is to differentiate them as transudate and exudate. The criteria established by Light et al. ${ }^{1}$ for differentiating exudate from transudate have been widely accepted.

In the present study, the markers which are assessed in both the transudate and exudate are uric acid, CRP and malondialdehyde. These markers have shown a significant difference between the groups. Uric acid being the marker for the oxidative stress and the natural antioxidant even was found to be lower in the exudative fluid compared to the Transudative effusion ( $4.16 \pm 0.96,7.68 \pm 0.78)$, respectively.

Table 1: Demonstrating the descriptive detail of the individuals included in the study

\begin{tabular}{|c|c|c|c|}
\hline & & Frequency & Percent \\
\hline \multirow[t]{2}{*}{ Gender } & Female & 28 & 37.3 \\
\hline & Male & 47 & 62.7 \\
\hline \multirow[t]{2}{*}{ Group } & Transudative & 21 & 28 \\
\hline & Exudative & 54 & 72 \\
\hline \multirow[t]{5}{*}{ Cause for pleural effusion } & Tuberculosis & 40 & 53.3 \\
\hline & Cardiac cause & 12 & 16 \\
\hline & Pulmonary & 3 & 4 \\
\hline & Cancer & 6 & 8 \\
\hline & Others & 14 & 18.7 \\
\hline
\end{tabular}

The frequencies and percentage of the variables distribution in the study 
Table 2: Demonstrating the t-test to measure the mean difference between the groups

\begin{tabular}{lllll}
\hline & & Transudative mean \pm SD & Exudative mean \pm SD & $p$ value \\
\hline Pleural & Protein $(\mathrm{gm} / \mathrm{dL})$ & $1.66 \pm 0.61$ & $5.11 \pm 0.83$ & $0.000^{* *}$ \\
& MDA $(\mathrm{nmol} / \mathrm{dL})$ & $210.03 \pm 30.77$ & $649.52 \pm 84.69$ & $0.000^{* *}$ \\
& CRP $(\mathrm{mg} / \mathrm{L})$ & $4.52 \pm 1.14$ & $19.69 \pm 3.81$ & $0.000^{* *}$ \\
& Uric acid $(\mathrm{mg} / \mathrm{dL})$ & $4.16 \pm 0.96$ & $0.000^{* *}$ \\
& Albumin $(\mathrm{gm} / \mathrm{dL})$ & $7.68 \pm 0.78$ & $2.5 \pm 0.60$ & $0.000^{* *}$ \\
& LDH $(\mathrm{U} / \mathrm{L})$ & $0.77 \pm 0.36$ & $1861.28 \pm 378.03$ & $0.000^{* *}$ \\
& Pleural/serum protein ratio & $106.05 \pm 45.82$ & $0.74 \pm 0.1$ & $0.000^{* *}$ \\
& Serum-effusion albumin gradient & $0.269 \pm 0.09$ & $0.73 \pm 0.10$ & $0.000^{* *}$ \\
& (SEAG) & $0.26 \pm 0.09$ & & $0.002^{* *}$ \\
\hline Pleural/serum LDH & $0.97 \pm 0.75$ & $7.49 \pm 3.345$ & $0.001^{* *}$ \\
& Protein $(\mathrm{gm} / \mathrm{dL})$ & $6.21 \pm 0.95$ & $6.88 \pm .71$ & 0.174 \\
& Albumin (gm/dL) & $2.9 \pm 0.88$ & $3.41 \pm 0.68$ & $0.01^{*}$ \\
\hline
\end{tabular}

Table demonstrating the mean difference between the two groups using the t-test, ${ }^{*} p$ value $<0.05,{ }^{* *} p$ value $<0.001 \mathrm{HS}$ (highly significant). LDH, lactate dehydrogenase, MDA, malondialdehyde, CRP, C-reactive protein

\begin{tabular}{|c|c|c|}
\hline Study & Subjects & Implication \\
\hline Papageorgiou et al. $^{7}$ & $\begin{array}{l}\text { Sixty-two subjects with transudate and exudative } \\
\text { pleural effusion- assessed for the oxidative stress in } \\
\text { the pleural fluid to differentiate the transudative and } \\
\text { exudative. }\end{array}$ & $\begin{array}{l}\text { The stress markers were significantly increased in the } \\
\text { pleural fluid with exudative nature }(p<0.001) \text {. }\end{array}$ \\
\hline Mangaraj et al. ${ }^{8}$ & Sixty subjects assessed pleural fluid MDA & $\begin{array}{l}\text { Study showed significant higher MDA levels in } \\
\text { exudative pleural fluid and positive correlation with } \\
\text { the pleural protein. }\end{array}$ \\
\hline Jain et al. ${ }^{4}$ & $\begin{array}{l}\text { Total of } 60 \text { subjects were assessed for pleural uric } \\
\text { acid as a marker for differentiation between exudate } \\
\text { and transudate cases. }\end{array}$ & $\begin{array}{l}\text { Significant increased levels of uric acid were seen in } \\
\text { transudate pleural effusion than exudative. }\end{array}$ \\
\hline Kiran, Komala ${ }^{5}$ & $\begin{array}{l}\text { Total of } 100 \text { subjects included comparing transudate } \\
\text { and exudate using MDA and lipid profile in pleural } \\
\text { effusion. }\end{array}$ & $\begin{array}{l}\text { MDA and total cholesterol levels in pleural fluid showed } \\
\text { significantly increased levels in exudates compared to } \\
\text { transudates }\end{array}$ \\
\hline Our study (2016) & $\begin{array}{l}\text { Seventy-five subjects were assessed to compare } \\
\text { levels of pleural CRP, uric acid and MDA in transudate } \\
\text { and exudate fluid. }\end{array}$ & $\begin{array}{l}\text { There is a significant increase in the MDA and Crp levels } \\
\text { and lower levels of uric acid in pleural fluid of exudative } \\
\text { compared to transudate. Levels of MDA in the pleural } \\
\text { fluid found to have a significantly very strong strength } \\
\text { of association with other markers; positive correlation } \\
\text { with CRP ( } r=0.952) \text {, pleural protein }(r=0.874) \text { and } \\
\text { negative correlation with uric acid }(r=-0.903) \text {. }\end{array}$ \\
\hline
\end{tabular}

Table 3: Pearson's correlation coefficient between pleural fluid MDA, CRP, protein, and uric acid ( $\mathrm{n}-75)$

\begin{tabular}{llll}
\hline & $M D A$ & $C R P$ & Uric acid \\
\hline CRP & $0.952^{* * *}$ & - & - \\
Uric acid & $-0.903^{* *}$ & $-0.845^{* *}$ & - \\
Protein & $0.874^{* *}$ & $0.859^{* *}$ & $-0.776^{* *}$ \\
\hline
\end{tabular}

The table showing the $r$ value of the variables; ${ }^{* *} p$ value $<0.001$, highly significant (HS)

CRP as the marker for the infection and an acute phase protein is increased in the exudative pleural fluid $19.69 \pm 3.81$ compared to transudative fluid $4.52 \pm 1.14$. MDA a marker for the membrane lipid peroxidative damage from the local free radical generation in the pleural fluid was found to be higher in the case of the exudative fluid $649.52 \pm 84.69$ against transudative $210.03 \pm 30.77$. Levels of MDA in the pleural fluid found to have a significantly very strong strength of association with other markers; positive correlation with CRP $(r=0.952)$, pleural protein $(r=0.874)$ and negative correlation with uric acid $(r=-0.903)$.

\section{Conclusion}

From the current study it is clear that the pleural fluid levels of CRP, uric acid and MDA are significantly different in transudate and exudate fluid. This knowledge can be used along with the light's criteria to strength the prediction of the type of fluid. The MDA and CRP was found to be higher in exudative fluid and uric 
acid in transudative fluid, probably due to the production of more of reactive oxygen species in the pleural locally in exudate fluid.

\section{References}

1. Light RW. Pleural Effusions: The Diagnostic Separation of Transudates and Exudates. Ann Intern Med. American College of Physicians 1972;77(4):507-516.

2. Storey $D$, Dines $D$, Coles D. Pleural effusion: A diagnostic dilemma. JAMA 1976;236(19):2183-2186.

3. Alfredo C, Luis HCT. Evaluation of different criteria for the separation of pleural transudates from exudates. Chest 1993;104(2):399-415.

4. Jain A, Kumar S, Jain R, B et al. A study of uric acid - a new biochemical marker for the differentiation between exudates and transudates in a pleural effusion cases a study of uric acid - a new biochemical marker for the differentiation between. Natl J community Med 2015;5(2):204208.

5. Usha Kiran P, Komala P. Comparison of transudates and exudates using malondialdehyde and lipid profile. Int J Biol Med Res 2015;6(1): 4737-4740.

6. Gupta KB. Evaluation of pleural fluid and serum MDA levels in differentiating transudative from exudative pleural effusions. Ind J Tub. 2002;49:97-100.

7. Papageorgiou E, Kostikas K, Kiropoulos T. Increased Oxidative Stress in Exudative Pleural Effusions. Chest 2005;128(5):3291-3297.

8. Mangaraj M, Kumari S, Nanda R, et al. Pleural fluid MDA and serumeffusion albumin gradient in pleural effusion. Indian J Clin Biochem 2008;23(1):81-84. 